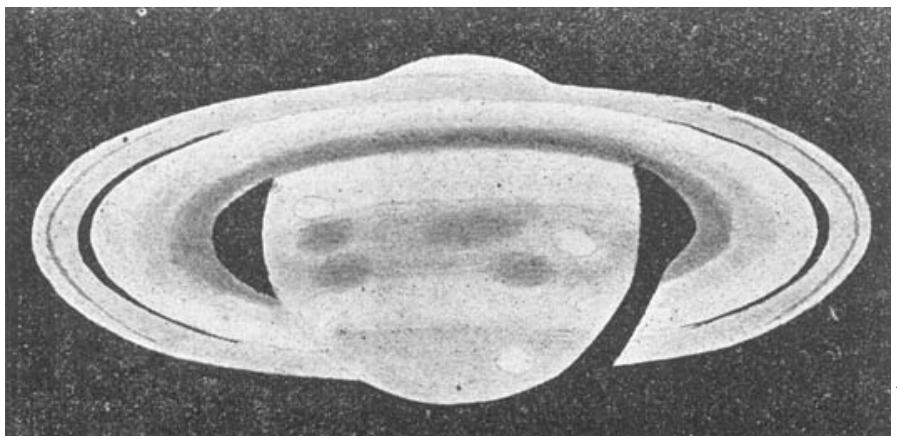

und rechts in der Mitte nicht genügend scharf. Mittlere zwei dunkle Flecke oft gut sichtbar. Nordpolar-Calotte, rechts einen hellen weissen Fleck enthaltend, etwas gräulich.
Aug. ${ }^{1} 57^{\mathrm{h}} 45^{\mathrm{m}}-8^{\mathrm{h}} 20^{\mathrm{m}}$ M. E. Z. Saturn zeigt reine Scheibe und ist scharf begrenzt. Encke'sche Trennung längere Zeit deutlich. Aequatorealband sehr ausgeprägt; links zwei dunkle Flecke auffallend rein. In der Mitte zwei und rechts unten ein dunkler Fleck ziemlich deutlich. Rechts oben ein heller Fleck scharf aufblitzend. Polarfleck sehr gut sichtbar. Ueber dem Aequator zarter Streifen.

Die dunklen Flecke wurden auch von Herrn B. Geiza von Podmaniczky auf den ersten Blick, ohne meine Zeichnung zu sehen, beobachtet, und die Position nach Augenmaass richtig entsprechend bestimmt.

Kis - Kartal, 1896 Aug. 26.

\section{A. Anton Wonaszek.}

\title{
Stars having peculiar spectra. New variable Stars in Crux and Cygnus.
}

\section{By Edward C. Pickering.}

A list of stars having peculiar spectra and found by Mrs. Fleming in her regular examination of the Draper Memorial photographs are given in the annexed table. The successive columns give the designation of the star, the approximate right ascension and declination for 1900 , the catalogue magnitude, and a brief description of the character of the spectrum, followed by additional remarks when required.

\begin{tabular}{|c|c|c|c|c|}
\hline Designation & RA I 900 & Decl. I 900 & Mag. & Description \\
\hline$-39: 3939$ & $8^{\mathrm{h}} \circ^{\mathrm{m}} \mathrm{I}$ & $-39^{\circ} 43^{\circ}$ & 2.5 & Peculiar. 5 Puppis \\
\hline ZC. I I $74^{2}$ & II. 1 I. 2 & $-57 \quad 23$ & 9 & Type IV \\
\hline GC. 15946 & 1135.0 & -720 & 8.5 & Type IV \\
\hline- & $12 \quad 26.9$ & -57 & - & Type III. Hydrogen lines bright. Variable \\
\hline-369 I 134 I & 177.0 & $-37 \circ$ & 9.1 & Gaseous Nebula. Gal. long. $317^{\circ}$ r2', lat. $-0^{\circ}$ I 5 \\
\hline GC. 22812 & 1647.0 & -42 I 2 & 5.8 & $H \beta$ bright. $\zeta^{1}$ Scorpii \\
\hline GC. 23694 & I 724.1 & -4947 & 2.9 & $F F$ bright. $\alpha$ Arae \\
\hline $\begin{array}{l}+44^{\circ} 3649 \\
+44^{\circ} 3679\end{array}$ & $\begin{array}{ll}20 & 54.4 \\
20 & 58.9\end{array}$ & $\begin{array}{l}+44.24 \\
+4425\end{array}$ & $\begin{array}{l}7.9 \\
6.8\end{array}$ & $\begin{array}{l}\text { Peculiar } \\
\text { Peculiar }\end{array}$ \\
\hline+44.3079 & $20 \quad 5^{8.9}$ & +4425 & 0.8 & Fecumar \\
\hline
\end{tabular}

The spectrum of the first of these stars is very remarkable and unlike any other as yet obtained. The continuous spectrum is traversed by three systems of lines. First, the hydrogen lines and the line $K$, which are dark, as in stars of the first type. Second, two bright bands or lines whose approximate wave lengths are 4652 and 4698 , which may be identical with the adjacent lines in spectra of the fifth type. Third, a series of lines whose approximate wave lengths are $3814,3857,3923,4028,4203$, and 4505 , the last line being very faint. These six lines form a rhythmical series like that of hydrogen and apparently are due to some element not yet found in other stars or on the earth. The formula of Balmer will not represent this series, but if we add a constant term and write

$$
\lambda={ }_{4} 65^{\circ} \frac{m^{2}}{m^{2}-4}-1032,
$$

we obtain for $m$ equal to $10,9,8,7,6$, and 5 , the wave lengths $3812 ; 3858,3928,4031,4$ I 99 , and 4504 . The deviations from the observed wave lengths have an average value of three tenmillionths of a millimetre, are systematic rather than accidental, and although small appear to be rather larger than might be expected from the errors of observation. A line of wave length 5168 is indicated for $m=4$, and, if present, could be observed visually, or photographed on a plate stained with erythrosin. The only other line found in the spectrum of this star has the wave length 4620 , and apparently does not belong to this series.

The fourth star in the table is a new variable in the constellation Crux. A comparison with eight adjacent catalogue stars gives its position for $1875, \mathrm{RA}=1 \mathbf{1}^{\mathrm{h}} 25^{\mathrm{m}} 27^{\mathrm{s}} \cdot 5$, Decl. $=-56^{\circ} 53^{\prime} 25^{\prime \prime}$. The period is about a year. The photographic magnitude, as derived from 57 plates, is 10.3 at maximum, and fainter than 13.2 at minimum.

The fifth of these objects is NGC. 6302 , whose spectrum, on a photograph taken on July 9,1896 , is shown to contain the bright lines characteristic of gaseous nebulae.

The presence of the bright hydrogen line in the sixth of these objects was found independently by Miss A. J. Cannon. 
The last two objects in the table have similar spectra, containing two bright bands resembling, and perhaps identical with, those in the spectrum of $\zeta$ Puppis.

In addition to the above objects a star in the constellation Cygnus, whose approximate position for 1900 is RA. $=2 \mathrm{I}^{\mathrm{h}} 3^{8^{\mathrm{m}} \cdot 8}$, Decl. $=+43^{\circ} 8^{\prime}$ has been found to be

Harvard College Observatory, 1896 Nov. 2. variable by Miss Louisa. D. Wells. Its period appears to be about 40 days and its photographic brightness varies from 7.2 to fainter than $1 \mathrm{r.2}$, an unusually large range for a variable having so short a period. Its position for 1900, as determined visually by Mr. O. C. Wendell, is $\mathrm{RA}=$ $21^{\mathrm{h}} 3^{8^{\mathrm{m}}} 4^{\mathrm{s}} 2 \mathrm{I}$, Decl. $=+43^{\circ} 7^{\prime} 34^{\prime \prime} 8$.

\section{Edward C. Pickering.}

Zusatz. Für den von Miss Wells entdeckten neuen Veränderlichen in Cygnus theilt Prof. $F$. Deichmüller d. d. 2 2. Nov. aus den Bonner AG.- und BD-Beobachtungen die folgenden Daten mit:

1) AG. Zone T. 88 I 869 Nov. I2. Tiele. Wolkig. BD. $+42^{\circ} .4 \mathrm{I} 90$ ist als $8{ }^{\mathrm{m}} 6$ beobachtet und dabei ist bemerkt 8.6 praec. $25^{\mathrm{s}} 8.5$ Bor. Hiernach ist der Ort dieses in BD. fehlenden Sterns :

$$
8^{\mathrm{m}} \cdot 6 \quad 2 \mathrm{I}^{\mathrm{h}} 38^{\mathrm{m}} 4^{8^{\mathrm{s}}}: \quad+43^{\circ} 7^{\prime} 40^{\prime \prime} 5 \text { (1900.0) }
$$

Das ist unzweifelhaft eine ältere Beobachtung des Wells' schen Sterns.

Z. 6081878 Aug. 5. Deichmüller. Klar, unruhig. BD. $+42^{\circ} .4190$ ist nur an den beiden letzten Fäden beobachtet und dabei kein praec. notirt.

Z. 6 I 51878 Sept. 14. Deichmüller. BD. $+42 \%_{4} 190$ ist als letzter Zonenstern beobachtet, als sich der Himmel mit Wolken überzog. Es ist kein praec. notirt.

2) BD. Zone 10541856 Oct. 20. Schönfeld. Sehr klare Luft. Der Stern fehlt.

Z. 1060 $185^{6}$ Oct. $2 \mathrm{r}$. Krueger. Luft etwas neblig und feucht; der Stern fehlt.

Z. 10731856 Oct. 25 . Krueger. Luft anfangs recht gut, später etwas neblig. (Anfang $2 \mathrm{I}^{\mathrm{h}} \mathrm{O}^{\mathrm{m}}$, Ende $\mathbf{2 2}^{\mathrm{h}} 8^{\mathrm{m}}$ ). Der Stern fehlt.

$K r$.

\section{Two brilliant meteors.}

\section{By $W: F$. Denning.}

On Sept. 10, 1896 the sky was beautifully clear in England and two fireballs made their appearance.

The first became visible at $9^{\mathrm{h}} 3^{\mathrm{m}}$ p. m. and moved swiftly leaving behind it a luminous streak for a period of 30 seconds. The second burst into view at $10^{\mathrm{h}} 26^{\mathrm{m}} \mathrm{p} . \mathrm{m}$. and moved slowly leaving a slight train and emitting, as it fell, a vivid bluish light which quite illuminated the sky and landscape. At Bristol I observed the second meteor as it descended almost vertically amongst the stars of Ursa Minor and Ursa Major, its apparent path being from $203^{\circ}+88^{\circ}$ to $154^{\circ}+69^{\circ}$.

From a comparison of the various observations I have worked out the following real paths:
G. M. T. of visibility

Height at beginning

Place

Geographical position

Height at ending

Place

Geographical position

Position of Earth point

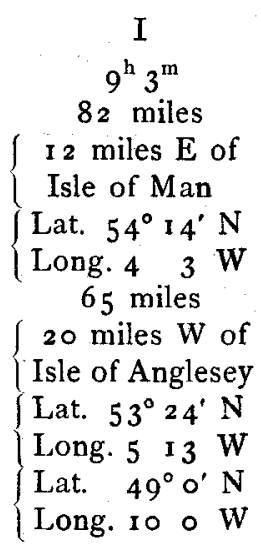

$9^{\mathrm{h}} 3^{\mathrm{m}}$

82 miles

I 2 miles $\mathrm{E}$ of

Isle of Man

$\left\{\begin{array}{l}\text { Lat. } 54^{\circ} 14^{\prime} \mathrm{N} \\ \text { Long. } 4 \quad 3 \mathrm{~W}\end{array}\right.$ 65 miles

20 miles $W$ of

Isle of Anglesey

Lat. $53^{\circ} 24^{\prime} \mathrm{N}$

Long. 5 I 3 W

Long. Io $\circ \mathrm{W}$

\section{II}

$10^{\mathrm{h}} 26^{\mathrm{m}}$

71 miles

Bromfield

Hereford

Lat. $52^{\circ} 2 \mathrm{I}^{\prime} \mathrm{N}$

Long. $24 \mathrm{I} \mathrm{W}$ 30 miles

Hope Hereford

Lat. $5^{\circ} \quad 9^{\prime} \mathrm{N}$ Long. $242 \mathrm{~W}$ Lat. ' $52^{\circ} I^{\prime} \mathrm{N}$ Long. $243 \mathrm{~W}$
Length of visible flight

Velocity per second Appar. astr. Radiant point Approximate star Incl. of meteor's descent Direction of flight from Apparent briliancy Number of observations

I
78 miles
31 miles
$72^{\circ}+42^{\circ}$
$\alpha$ Aurigae
$12^{\circ} /^{\circ}$
$\mathrm{NE} \mathrm{by} \mathrm{N}$
$>9$
7

II

44 miles 15 miles $330^{\circ}+71^{\circ}$ $71^{\circ}$ $\mathrm{N}$. $5 \times 9$ 15 $\beta$ Cephei

The great difference in the radiant points proves the two bodies to have belonged to widely distinct systems.

The parent or derivative meteor showers from which they came agree with the following radiants in my catalogue published in the Monthly Notices of the Royal Astronomical Society for May I 890 :

\section{I}

No. 520 I885 Sept. I $2-1573^{\circ}+43^{\circ}$ Swift meteors

No. 549 1879 Sept. $15-1672+41\}$ with streaks

\section{II}

No. 5 I 8 I885 Sept. $4-9 \quad 335+7$ I slow, bright

Fireballs are generally numerous during the period Sept. 5 to 15 but they often belong to a rich shower from the point $61^{\circ}+3^{\circ}$ near $\varepsilon$ Persei. - It is fortunate therefore to have recorded two fine meteors from other systems. 